\title{
The role of rapid tissue expansion in separating xipho-omphalopagus conjoined twins in Vietnam
}

\author{
Tran Thiet Son ${ }^{1,2,3}$, Pham Thi Viet Dung ${ }^{1}$, Ta Thi Hong Thuy ${ }^{1}$, Vu Duy Kien ${ }^{4}$, \\ Nguyen Thanh Liem ${ }^{5}$ \\ ${ }^{1}$ Department of Plastic and Reconstructive Surgery, Hanoi Medical University Hospital, Hanoi; ${ }^{2}$ Department of Plastic Reconstructive \\ Aesthetic Surgery, Saint Paul Hospital, Hanoi; ${ }^{3}$ Department of Plastic and Reconstructive Surgery, Bach Mai Hospital, Hanoi; ${ }^{4}$ OnCare \\ Medical Technology Company Limited, Hanoi; ${ }^{5}$ Department of Pediatric Surgery, Vietnam National Children's Hospital, Hanoi, Vietnam
}

\begin{abstract}
Conjoined twins are rare, and each set of conjoined twins has a unique conjoined anatomy. It is necessary to perform separation to increase the chance of patient survival. Tissue expansion is an advanced technique for providing sufficient soft tissue and skin for wound closure. We report the successful application of rapid tissue expansion in 10-month-old xipho-omphalopagus conjoined twins in Vietnam. A tissue expander was placed on the anterior body between the sternum and umbilicus with a baseline of $70 \mathrm{~mL}$ sterile saline $(0.9 \% \mathrm{NaCl})$. The first injection into the tissue expander began on the 6th day after expander insertion, and injections continued every 2 days with approximately $30-70 \mathrm{~mL}$ per injection according to the expansion of the skin. The expander reached $335 \mathrm{~mL}$ after six injections and within 10 days. In order to prepare for surgical separation, expansion was completed on the 15th day after insertion. The expanded skin area was estimated to be $180 \mathrm{~cm}^{2}$, which was sufficient to cover both patients' skin deficiencies. The twins presented for surgical separation 6 days following the completion of tissue expansion. Both babies were discharged in good health 1 month after separation.
\end{abstract}

Keywords Xipho-omphalopagus conjoined twins / Conjoined twins / Tissue expansion / Separation / Vietnam

\author{
Correspondence: Tran Thiet Son \\ Department of Plastic and \\ Reconstructive Surgery, Hanoi \\ Medical University Hospital, No.1 Ton \\ That Tung Street, Hanoi 116001, \\ Vietnam \\ Tel: +84-903444244 \\ E-mail: tranthietson@hmu.edu.vn
}

Received: December 12, 2020 - Revised: March 28, 2021 • Accepted: April 12, 2021

pISSN: 2234-6163 • elSSN: 2234-6171 • https://doi.org/10.5999/aps.2020.02467• Arch Plast Surg 2021;48:378-383

\section{INTRODUCTION}

Conjoined twins are rare and occur at an estimated rate of approximately $1: 50,000$ to $1: 200,000$ live births $[1,2]$. Most conjoined twins are female (about $75 \%$ of cases) [2]. Conjoined twins are often clinically classified as thoracopagus, omphalopagus, pygopagus, ischiopagus, and craniopagus [3], of which omphalopagus twins are the second most common type [2]. As a more specific classification, xipho-omphalopagus twins are those conjoined in the xiphoid area. The separation of conjoined twins is considered necessary since separation increases their chance of survival. In addition, separation maximizes patients' available functions and enhances quality of life [4]. Although clinical classifications exist, each set of conjoined twins has a unique conjoined anatomy. Therefore, to achieve successful separation, a detailed preoperative plan must be developed, and coordination across multiple medical specialties is required $[2,4,5]$, given that the surgical challenges of separating shared 
organs, wound closure, and reconstruction require specific attention [4-6].

Tissue expansion is an advanced technique for providing sufficient tissue and skin area, as required during separation for wound closure [5-7]. Although previous studies in other countries have applied the tissue expansion technique to varying extents $[4,5,7,8]$, no studies have reported the application of this technique in Vietnam. In this article, we report on and highlight lessons learned from the successful application of the rapid tissue expansion method in 10-month-old xipho-omphalopagus conjoined twins in Vietnam.

\section{CASE}

Female xipho-omphalopagus conjoined twins were delivered by cesarean section at 36 weeks of gestation to a 29-year-old woman with a history of two pregnancies and one birth. The pregnant woman had no history of disease during the antenatal period. This patient was diagnosed with twins, but conjoined twins were unexpected. The conjoined twins were detected by ultrasound only when the pregnant woman was admitted to the hospital for delivery at a provincial hospital. Thus, the doctors decided to perform a cesarean section. The conjoined twins were safely delivered with a combined weight of $3.0 \mathrm{~kg}$. The twins were joined at various organs, including the pericardial membrane, diaphragm, liver, and small intestine. In addition, baby $\mathrm{A}$ had a heart defect in the right chest and baby $\mathrm{B}$ had a hemangio$\mathrm{ma}$ in the left arm. The twins were also joined at the upper ab-

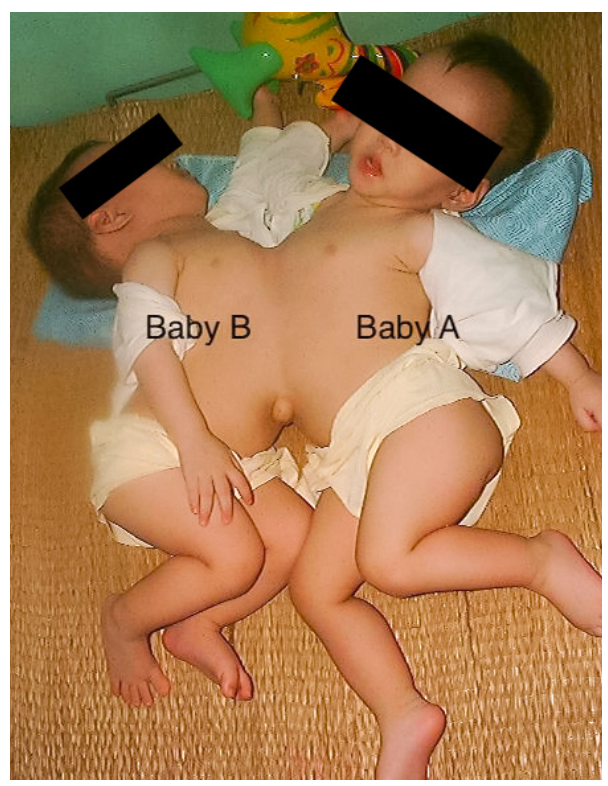

Fig. 1. A pair of 10-month-old xipho-omphalopagus conjoined twins. The twins presented with a combined weight of about $7 \mathrm{~kg}$, and they were prepared for tissue expansion. domen from the sternum to umbilicus. Above and below the area of fusion, they showed two normal upper and lower limbs. The twins were placed under nursing care and followed up at the provincial hospital for 1.5 months. The twins were then referred to our hospital for continued follow-up examinations and a planned intervention. The twins were healthy and well-nourished. A multidisciplinary team that was formed in preparation for the intervention determined that separation should be delayed until the twins gained adequate weight with independent feeding and until they could tolerate the extended and intensive surgical procedure. It was thus suggested that surgical separation should proceed when the twins reached 10 months.

The twins presented with a combined weight of approximately $7 \mathrm{~kg}$ for surgical preparation (Fig. 1). The area of fusion from the sternum to the umbilicus was $18 \mathrm{~cm}$ in length and $6 \mathrm{~cm}$ in width. The right and left twins were marked as babies A and B, respectively (Fig. 2). The estimated skin and tissue surface area of $110 \mathrm{~cm}^{2}$ was considered to be deficient. In anticipation of insufficient skin coverage following twin separation, we determined that tissue expansion would be needed in order to allow closure. The area of fusion deviated from the midline, indicating that the twins' anterior body had a larger area than the posterior body. A tissue expander was thus placed on the anterior body between the sternum and umbilicus because this placement fit the bottom portion of the tissue expander (Fig. 3). The tissue expander was a rectangular prism with dimensions of $7 \mathrm{~cm}$ (width) $\times 9.5 \mathrm{~cm}$ (length) $\times 5 \mathrm{~cm}$ (height), providing a theoretical volume of approximately $330 \mathrm{~mL}$. A 4-cm skin incision was made parallel to, and approximately $2.5 \mathrm{~cm}$ from, one edge of the expander, on the fusion of the sternum (Fig. 4).

A subcutaneous cavity with dimensions of $8 \mathrm{~cm} \times 11 \mathrm{~cm}$ was made, and the tissue expander was placed between the subcutaneous and abdominal wall. We used three layers of nylon sutures

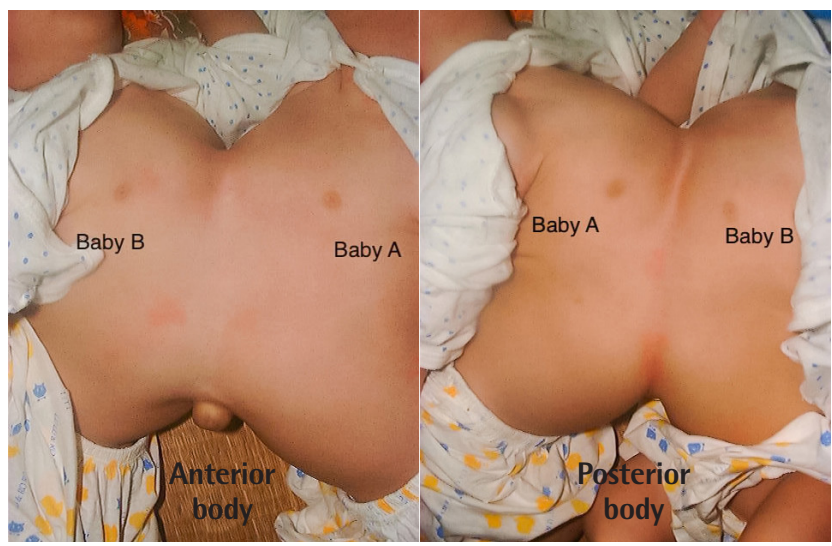

Fig. 2. Close-up photograph of the fusion area. The twins' anterior body and posterior body. 


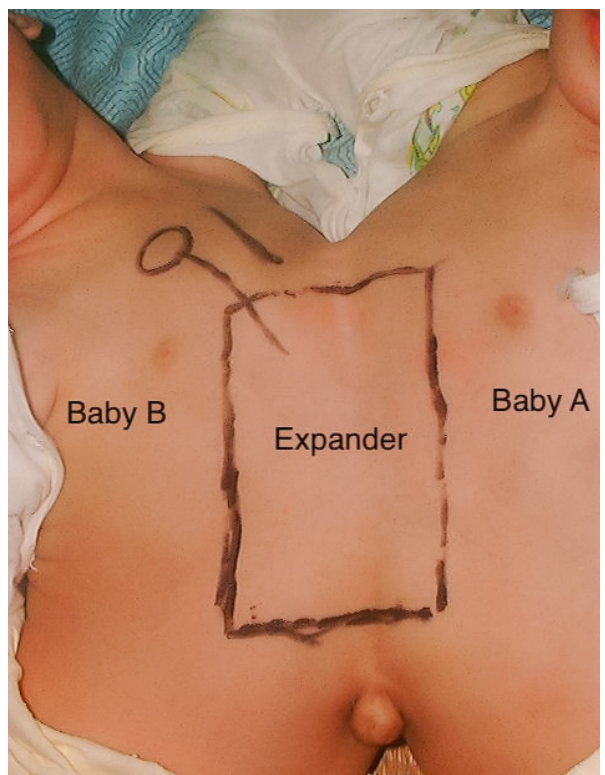

Fig. 3. Designated area for the tissue expander. The twins' anterior body was selected to insert the tissue expander. The team measured and estimated the location and area for the tissue expander. It was decided to place the injection port on baby B's chest.

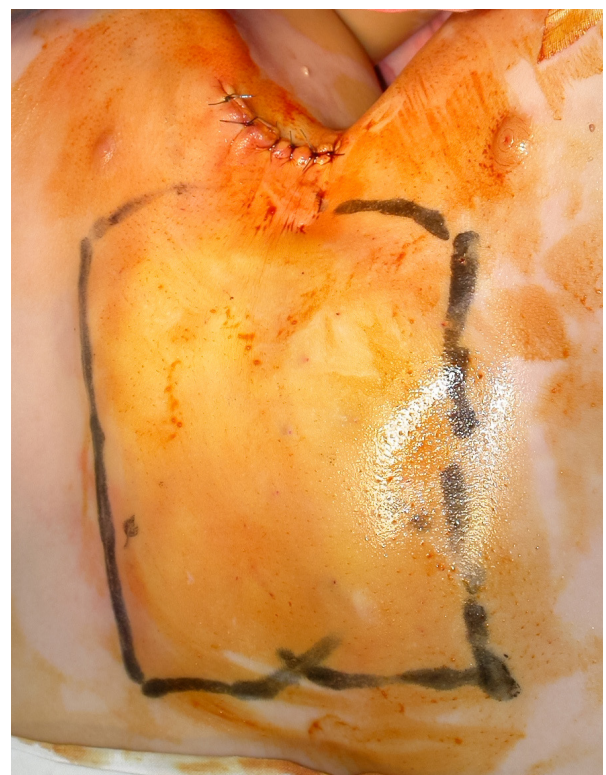

Fig. 4. After inserting the tissue expander. The tissue expander with rectangular prism was inserted into the twins' anterior body. A 4-cm skin incision was made parallel to one edge of the expander, on the fusion of the sternum. Three layers of nylon sutures were used to close the incision.

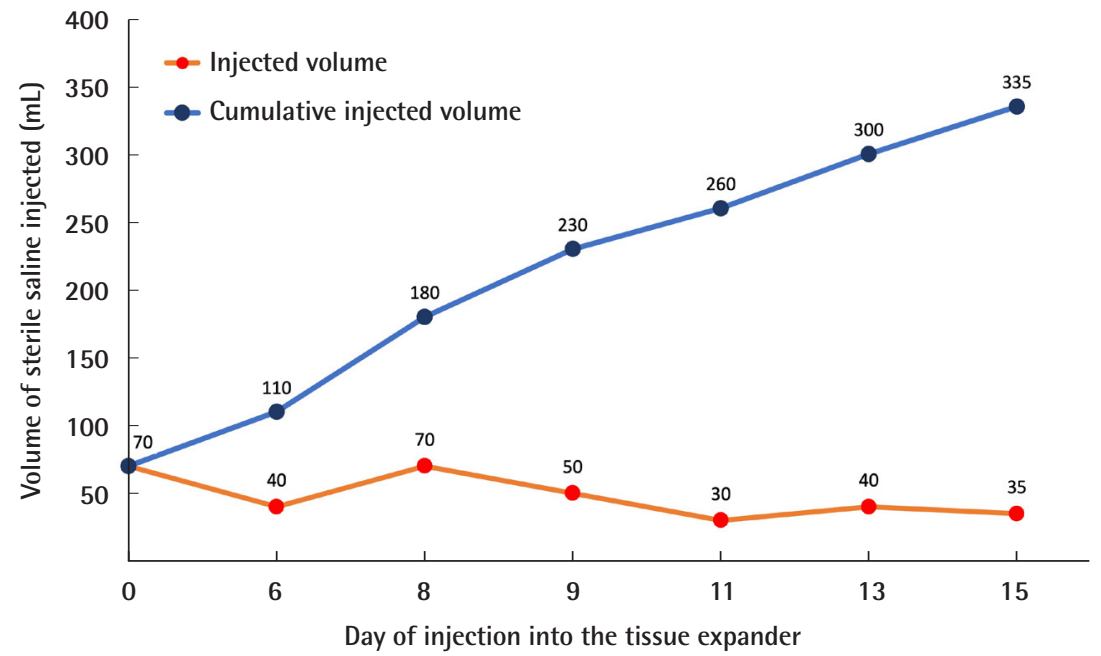

Fig. 5. Tissue expander injection schedule and volume.

to close the incision. A portion of the bottom of the expander contacted the twins' ribs to avoid backward stretching during expansion. The injection port was then placed on baby B's chest, and the expander was filled with a baseline of $70 \mathrm{~mL}$ sterile saline $(0.9 \% \mathrm{NaCl})$ to stop blood from entering the dissection cavity. The expander was well-tolerated by the twins with no signs of local or systemic reactions. The first injection into the expander began on the 6th day of tissue expander insertion, before removing the sutures. We performed further injections into the expander every 2 days with approximately $30-70 \mathrm{~mL}$ per injection according to the expansion of the skin (Fig. 5). The ex- pander reached $335 \mathrm{~mL}$ (or slightly higher than the expander's theoretical volume) after six injections and within 10 days (Fig. 6). In order to prepare for surgical separation, expansion was completed on the 15th day after insertion. The expanded skin area was estimated at $180 \mathrm{~cm}^{2}$, which was sufficient to cover both patients' skin deficiencies.

The twins presented for surgical separation 6 days following the end of tissue expansion. The surgical team was from our hospital. The total time for surgical separation and reconstruction was approximately 10 hours. The abdominal wall was closed in two layers, with the fascial muscle layer closed directly, using part 


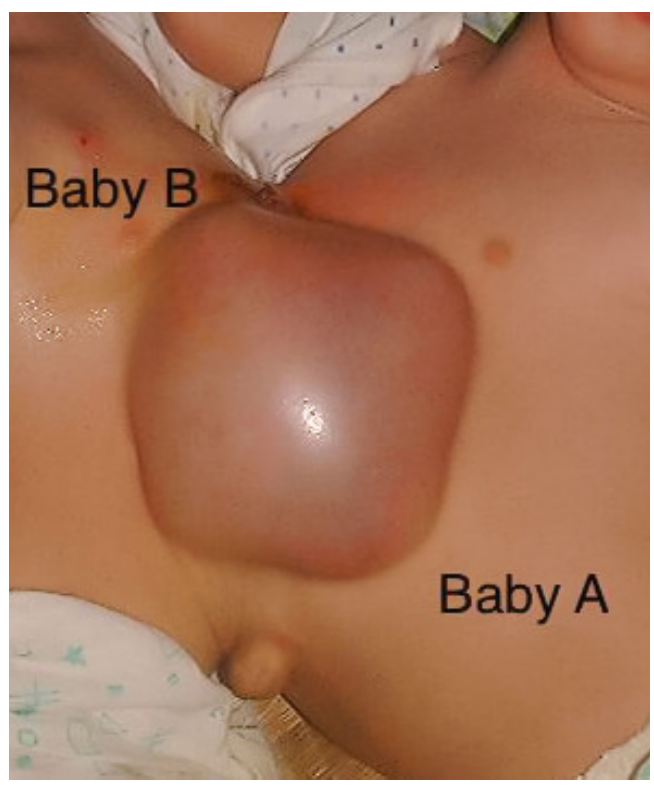

Fig. 6. The end of the injection process. Close-up photograph of the tissue expander when it reached $335 \mathrm{~mL}$.

of the fibrous layer around the expander, and the expanded skin of the chest was closed directly after the Z-lines incision. This allowed usage of the expanded skin at the ends of the expander. The sternal skin area was more challenging to close than the abdominal skin, so several additional incisions were made to enhance the tissue expander's effect during closure. Within 72 hours after surgery, both babies were put on positive airway pressure and high-flow nasal cannulation. Both children had a good healing process on day 16 (Fig. 7), and they were discharged in good health 1 month after separation (Fig. 8).

\section{DISCUSSION}

Tissue expansion is an increasingly popular technique because it provides soft tissue for closure and reconstruction in surgery. This is the first case of rapid tissue expansion applied to the surgical separation of xipho-omphalopagus conjoined twins to be reported in Vietnam. We found that tissue expansion was safe and provided adequate soft-tissue coverage for each closure after separation, and we therefore suggest that this successful implementation can be a lesson for similar procedures.

Wound closure and reconstruction usually pose major challenges for surgeons during the separation of conjoined twins $[4,5,9]$. If only one of the twins can be saved, soft-tissue coverage is simpler given that it is possible to use skin flaps from the lost baby for the surviving baby $[10,11]$. However, wound closure and reconstruction become more difficult if both babies can be saved, given that the area of skin deficiency is larger, especially in xipho-omphalopagus conjoined twins $[2,4,5]$. Tissue

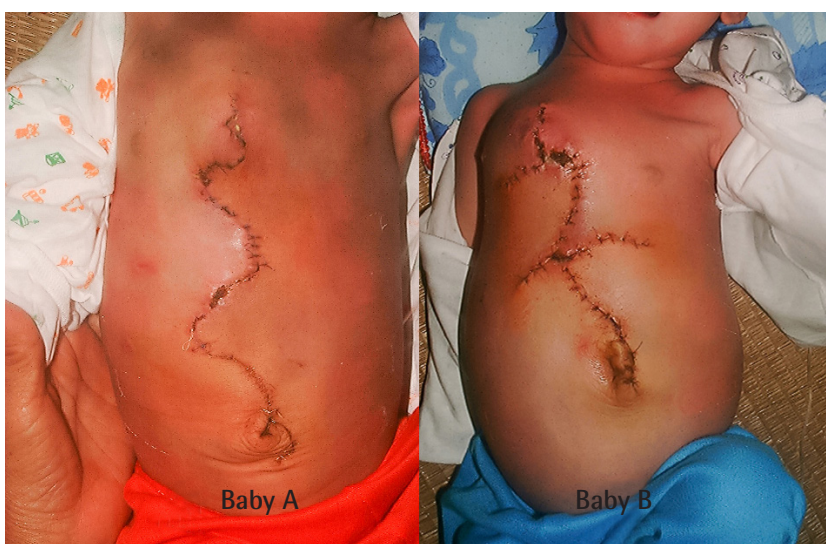

Fig. 7. Healing process after surgical separation. The healing process on day 16 in babies.

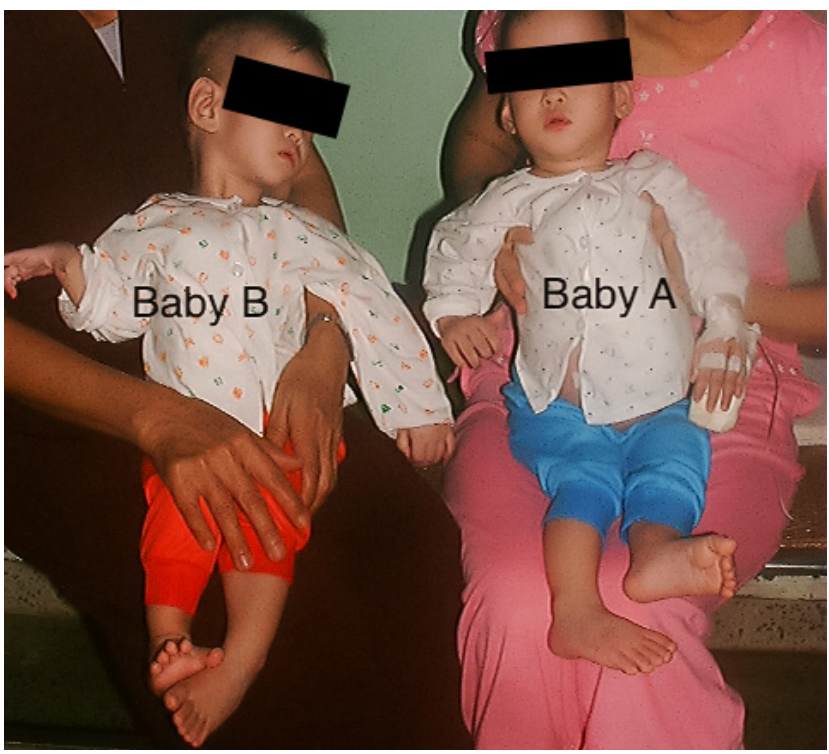

Fig. 8. Babies A and B 1 month after surgical separation on the day of discharge.

expansion is considered to be the most advanced and suitable method for providing adequate soft-tissue coverage for closure and reconstruction $[6,7,9]$, and we used this technique to prepare for surgery due to the technique's known benefits and our experience with the technique.

Tissue expansion using different approaches has been described previously $[4,5,8,12]$. However, the tissue expander is generally inserted between the subcutaneous layer and the abdominal wall muscle, which is the most suitable space for expanding the skin and soft tissue because it reduces the risk of pressure on the abdomen and internal organs during injection into the expander $[7,13]$. Unlike previous authors [14-16], we performed skin incision parallel to the edge of the expander, which facilitated dissection of the expander cavity and could stop bleeding. The most challenging issue in skin and tissue ex- 
pansion is making a firm skin incision against the pressure of the expansion device itself while avoiding disrupting or tearing the initial incision. In previous studies, surgeons waited for complete healing at the incision (about 2-3 weeks) before beginning expander injections $[4,5,7]$, whereas we improved upon the technique by using nylon sutures (sizes 3.0 or 4.0 ) in three layers to close the incision, using the first layer to isolate the tissue expander, the second layer to close the subcutaneous layer, and the third layer to close the skin layer. A noteworthy difference from other approaches is that the first-layer suture helped isolate the tissue expander from the incision, thus relieving pressure from the expander on the incision and reducing the risk of disruption of the incision. With the use of the first layer of sutures, we were thus able to perform injections into the expander earlier than reported by other authors; we began expansion injections on the 6th day after inserting the expander without waiting for complete healing. In addition, the expansion injections were done every 2 days with a capacity of $30-70 \mathrm{~mL}$ depending on the skin expansion, thus shortening the time required for tissue expansion. We have successfully applied this specific three-layer suture technique in more than 200 cases of tissue and skin deficiency in patients with various diseases and conditions (e.g., post-burn scarring, ulcerated hematoma, melanoma, congenital defects, and post-injury scarring).

We also realize that choosing the correct position to insert the expander plays an important role in the success of the tissue expansion process. Since the conjoined twins were fused with a deviation from the midline, the front side was selected for insertion of the expander because there was more space than on the back side. In some previous cases, two or three tissue expanders were used depending on the specific conditions $[4,5]$. In our case, the distance between baby A's left nipple and baby B's right nipple was longer in the fused frontal area than in the fused area on the back, thus allowing the expander to be placed without affecting the mammary glands of both babies. Furthermore, this fused area was relatively flat, which facilitated tissue expansion and the removal of the expander. In addition, we believe that the use of Z-incisions also contributed to successful surgical closure, as Z-incisions utilize and maximize the skin stretching from the sides of the expander [17]. During tissue expansion, a fibrotic capsule around the expander formed and could serve as a source of tissue along with the abdominal wall muscles used for surgical closure. Typically, this fibrotic capsule will last for up to 1824 months, which is enough time for both babies' abdominal wall structures to complete development.

We implemented rapid tissue expansion with six injections in 11 days, a procedure similar to that reported by Hilfiker et al. (who completed the process in 14 days) [12]. Our decreased stretching time was likely due, in part, to the increased speed with which skin can expand under a stretching force in young children, and also due, in part, to the injection of the expander (when the development of a fibrotic capsule was negligible in an early stage) in the first few weeks, lessening the effects of the fibrotic capsule on tissue expansion. Using the rapid tissue expansion technique, which provided adequate skin and tissue for surgical closure, we decreased the time that the expanders were implanted in the body, thereby reducing the risk of infection.

The design of skin flaps for the tissue expansion process may also be important in closing the abdominal wall $[18,19]$. Since the tissue expander was a rectangular prism, the skin above the top (thymus area) and bottom (near the navel) of the tissue expander expanded more than other areas, thus helping cover the areas that needed the most skin and soft tissue. We did not observe any complications related to infection or necrosis around the tissue expansion area. However, we believe that there is always a risk of these complications if sterility cannot be ensured during tissue expansion $[6,9]$. Spitz et al. reported that they declined to use subcutaneous tissue expanders due to the risk of infection $[8,10]$. Therefore, it is necessary to closely monitor the tissue expansion area to detect and quickly process signs of potential complications.

In summary, rapid tissue expansion was implemented safely and provided adequate tissue and skin for closure required by separation of xipho-omphalopagus conjoined twins. Using a three-layer suture method with non-absorbable sutures to close the incision enabled the early initiation of tissue expansion. Early injection into the tissue expander shortened the tissue expansion time, and, in particular, likely reduced the risk of infection at the expander insertion site. In addition to surgical separation, planning and implementing the tissue expansion itself is highly important for improving closure success.

\section{NOTES}

\section{Conflict of interest}

No potential conflict of interest relevant to this article was reported.

\section{Ethical approval}

The study was performed in accordance with the principles of the Declaration of Helsinki. Written informed consent was obtained.

\section{Patient consent}

The patients' guardian provided written informed consent for the publication and the use of patient's images. 


\section{Author contribution}

Conceptualization: TT Son, NT Liem. Writing - original draft: TT Son, VD Kien. Writing - review \& editing: TT Son, PTV Dung, TTH Thuy, VD Kien, NT Liem. Approval of final manuscript: all authors.

\section{ORCID}

Tran Thiet Son https://orcid.org/0000-0001-6739-1059 Pham Thi Viet Dung https://orcid.org/0000-0002-3912-0195 Ta Thi Hong Thuy https://orcid.org/0000-0001-5536-6075 Vu Duy Kien https://orcid.org/0000-0002-4333-8912 Nguyen Thanh Liem https://orcid.org/0000-0002-4036-0161

\section{REFERENCES}

1. Mutchinick OM, Luna-Munoz L, Amar E, et al. Conjoined twins: a worldwide collaborative epidemiological study of the International Clearinghouse for Birth Defects Surveillance and Research. Am J Med Genet C Semin Med Genet 2011;157C:274-87.

2. Spitz L, Kiely EM. Experience in the management of conjoined twins. Br J Surg 2002;89:1188-92.

3. Spencer R. Anatomic description of conjoined twins: a plea for standardized terminology. J Pediatr Surg 1996;31:941-4.

4. Trost JG Jr, Lin LO, Clark SJ, et al. Separation of thoracoomphalo-ischiopagus conjoined twins: surgical planning, management, and outcomes. Plast Reconstr Surg 2016;138: 1064-72.

5. Jackson OA, Low DW, LaRossa D. Conjoined twin separation: lessons learned. Plast Reconstr Surg 2012;129:956-63.

6. Zubowicz VN, Ricketts R. Use of skin expansion in separation of conjoined twins. Ann Plast Surg 1988;20:272-6.

7. Clifton MS, Heiss KF, Keating JJ, et al. Use of tissue expanders in the repair of complex abdominal wall defects.J Pediatr
Surg 2011;46:372-7.

8. Spitz L, Capps SN, Kiely EM. Xiphoomphaloischiopagus tripus conjoined twins: successful separation following abdominal wall expansion. J Pediatr Surg 1991;26:26-9.

9. Fallon SC, Olutoye OO. The surgical principles of conjoined twin separation. Semin Perinatol 2018;42:386-92.

10. Spitz L, Stringer MD, Kiely EM, et al. Separation of brachiothoraco-omphalo-ischiopagus bipus conjoined twins. J Pediatr Surg 1994;29:477-81.

11. Ali KA. Management of conjoined twins during neonatal period. Ann Pediatr Surg 2010;6:105-10.

12. Hilfiker ML, Hart M, Holmes R, et al. Expansion and division of conjoined twins. J Pediatr Surg 1998;33:768-70.

13. Foglia R, Kane A, Becker D, et al. Management of giant omphalocele with rapid creation of abdominal domain. J Pediatr Surg 2006;41:704-9.

14. Radovan C. Tissue expansion in soft-tissue reconstruction. Plast Reconstr Surg 1984;74:482-92.

15. Wagh MS, Dixit V. Tissue expansion: concepts, techniques and unfavourable results. Indian J Plast Surg 2013;46:33348.

16. Braun TL, Hamilton KL, Monson LA, et al. Tissue expansion in children. Semin Plast Surg 2016;30:155-61.

17. Liu YJ. The theory and practical use of the Z-incision for the relief of scar contractures. In: Hultman CS, editor. 50 Studies every plastic surgeon should know. Boca Raton: CRC Press; 2014 p. 9.

18. Argenta LC. Controlled tissue expansion in reconstructive surgery. Br J Plast Surg 1984;37:520-9.

19. Bauer BS, Margulis A. The expanded transposition flap: shifting paradigms based on experience gained from two decades of pediatric tissue expansion. Plast Reconstr Surg 2004;114:98-106. 